\title{
Retraction Note: Growth property at infinity of harmonic functions
}

\author{
Zongcai Jiang ${ }^{1}$, Linbo Hou ${ }^{2 *}$ and Corchado Peixoto-de-Büyükkurt ${ }^{3}$
}

The original article can be found online at https://doi.org/10.1186/ s13660-015-0919-6

"Correspondence: Ihou79@qq.com ${ }^{2}$ College for Nationalities, Huanghe Science and Technology College, Zhengzhou, 450063, China Full list of author information is available at the end of the article

\section{Retraction note}

The Editor-in-Chief has retracted this article [1] because it significantly overlaps with previously published articles $[2,3]$ and an article by another author that was simultaneously under consideration at another journal [4]. The article also shows evidence of authorship manipulation. In addition, the identity of the third author could not be verified: the University of Delaware have confirmed that Cochardo Peixoto-de-Büyükkurt has not been affiliated with their institution. The authors have not responded to any correspondence regarding this retraction.

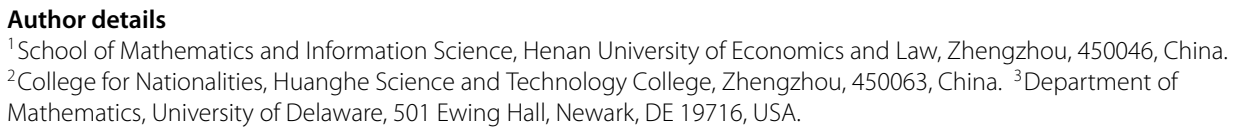

\section{Publisher's Note}

Springer Nature remains neutral with regard to jurisdictional claims in published maps and institutional affiliations.

Published online: 08 September 2020

\section{References}

1. Jiang, Z., Hou, L., Peixoto-de-Büyükkurt, C.: Growth property at infinity of harmonic functions. J. Inequal. Appl. 2015 401 (2015). https://doi.org/10.1186/s13660-015-0919-6

2. Qiao, L., Deng, G.: Growth of certain harmonic functions in an $n$-dimensional cone. Front. Math. China 8, 891-905 (2013). https://doi.org/10.1007/s11464-012-0253-y

3. Xue, G., Yuzbasi, E.: RETRACTED ARTICLE: Fixed point theorems for solutions of the stationary Schrödinger equation on cones. Fixed Point Theory Appl. 2015, 34 (2015). https://doi.org/10.1186/s13663-015-0275-8

4. Li, Z:: RETRACTED ARTICLE: Boundary behaviors of modified Green's function with respect to the stationary Schrödinger operator and its applications. Bound. Value Probl. 2015, 242 (2015). https://doi.org/10.1186/s13661-015-0499-x

\section{Springer}

(c) The Author(s) 2020. This article is licensed under a Creative Commons Attribution 4.0 International License, which permits use, sharing, adaptation, distribution and reproduction in any medium or format, as long as you give appropriate credit to the original author(s) and the source, provide a link to the Creative Commons licence, and indicate if changes were made. The images or other third party material in this article are included in the article's Creative Commons licence, unless indicated otherwise in a credit line to the material. If material is not included in the article's Creative Commons licence and your intended use is not permitted by statutory regulation or exceeds the permitted use, you will need to obtain permission directly from the copyright holder. To view a copy of this licence, visit http://creativecommons.org/licenses/by/4.0/. 